\title{
Reversible cerebral vasoconstriction syndrome with reversible renal artery stenosis
}

Figure Brain and vascular imaging findings

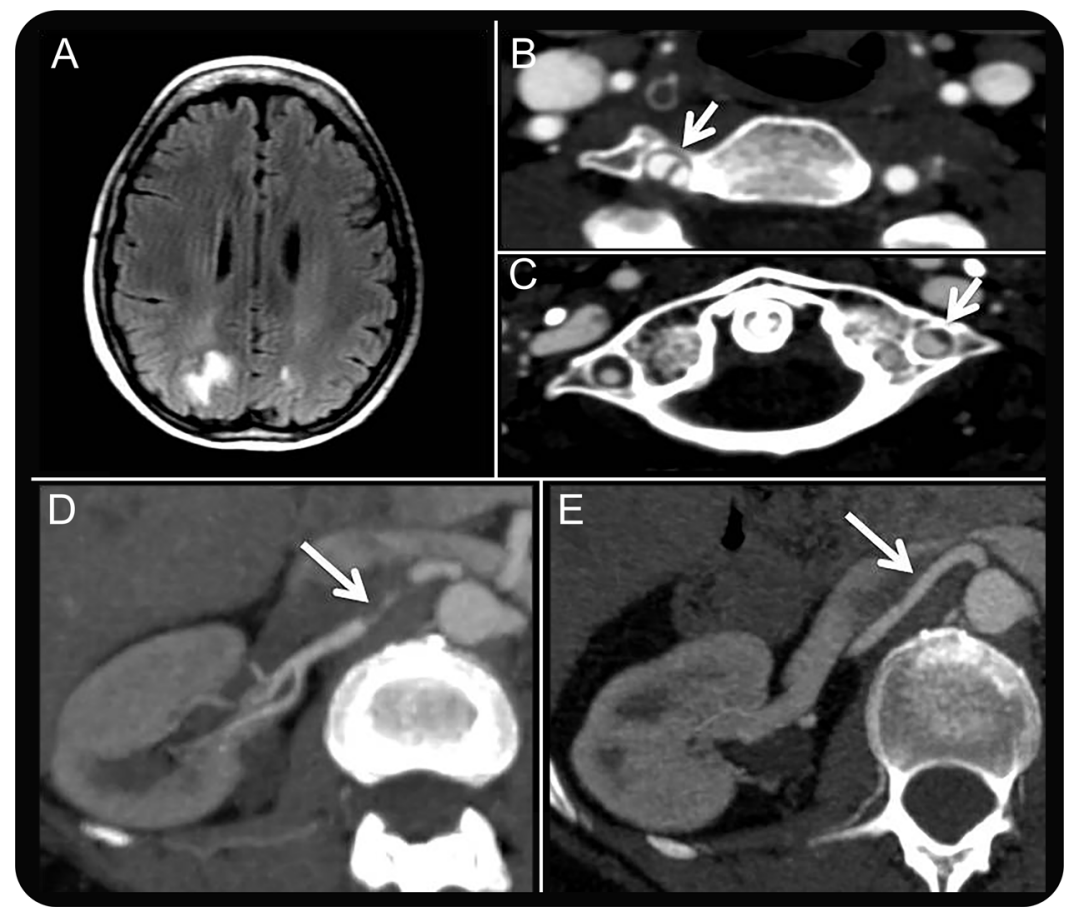

Brain MRI shows crescentic cortical-subcortical T2-hyperintense lesions in both occipital-parietal lobes (A). Head/neck CT angiography shows focal dissections $(\mathrm{B}, \mathrm{C})$ and irregularities affecting both vertebral arteries. Abdomen $\mathrm{CT}$ angiography shows right renal artery stenosis (D). All abnormalities resolved spontaneously within a few months, including renal artery narrowing (E).

A 41-year-old woman presented with thunderclap headaches, cortical blindness, generalized seizures, and severe hypertension. Brain imaging (figure) showed features of reversible cerebral vasoconstriction syndrome (RCVS) and posterior reversible encephalopathy syndrome. ${ }^{1}$ Her neurologic examination improved, but severe hypertension persisted. Abdomen CT angiography showed right renal artery narrowing with possible dissection, initially attributed to fibromuscular dysplasia (FMD). Renal angioplasty was considered; however, she was discharged on multiple antihypertensive agents. Her blood pressure normalized, and parenchymal lesions and vertebral/renal artery abnormalities showed complete resolution on follow-up at 7 months. This case emphasizes that RCVS can affect the extracerebral systemic arteries, ${ }^{2}$ and can be misinterpreted as FMD.

\section{Shibani S. Mukerji, MD, PhD, Bradley R. Buchbinder, MD, Aneesh B. Singhal, MD}

From Massachusetts General Hospital and Harvard Medical School (S.S.M., B.R.B., A.B.S.); and Dana Farber Cancer Institute (S.S.M.), Boston, MA.

Author contributions: Shibani S. Mukerji: drafting/revising the manuscript, analysis or interpretation of data, accepts responsibility for conduct of research and final approval. Bradley R. Buchbinder: drafting/revising the manuscript, study concept or design, analysis or interpretation of data, accepts responsibility for conduct of research and final approval. Aneesh B. Singhal: drafting/revising the manuscript, study concept or design, analysis or interpretation of data, accepts responsibility for conduct of research and final approval, acquisition of data, study supervision.

Study funding: No targeted funding reported. 
Disclosure: S. Mukerji and B. Buchbinder report no disclosures relevant to the manuscript. A. Singhal has served as a Medicolegal expert witness. Go to Neurology.org for full disclosures.

Correspondence to Dr. Singhal: asinghal@partners.org

1. Mawet J, Boukobza M, Franc J, et al. Reversible cerebral vasoconstriction syndrome and cervical artery dissection in 20 patients. Neurology 2013;81:821-824.

2. John S, Hajj-Ali RA, Min D, Calabrese LH, Cerejo R, Uchino K. Reversible cerebral vasoconstriction syndrome: is it more than just cerebral vasoconstriction? Cephalalgia 2015;35:631-634.

\section{Get Connected. Stay Connected.}

Connect with the American Academy of Neurology's popular social media channels to stay up-todate on the latest news and breakthroughs in neurology, and network with peers and neurology thought leaders. Visit $A A N . c o m / C o n n e c t$.

\section{Increasing the Value of YOUR AAN Membership}

\section{FREE MOC Benefits Starting January 1, 2015}

You asked and we listened. As of January 1, 2015, your robust AAN membership package includes FREE* access to online learning programs designed specifically to help you take the necessary steps toward fulfilling your maintenance of certification (MOC) requirements as mandated by the ABPN: NeuroPI ${ }^{\text {SM }}$, NeuroSAE $^{\circledR}$, NeuroLearn $^{\text {SM }}$.

Learn more at $A A N$.com/view/MOC

* \$0 purchase price excludes Student members and Nurse Practitioner/Physician Assistant members at the lower dues rate. Free access is limited to one course per program at a time.

\section{Minutes Pack a Punch}

\section{Neurology ${ }^{\circledR}$ Podcasts}

- Interviews with top experts on new clinical research in neurology

- Editorial comments on selected articles

- Convenient-listen during your commute, at your desk, or even at the gym

- On demand-it's there when you want it

- Fun and engaging

- New topic each week

- FREE

Listen now at www.aan.com/podcast 


\section{Neurology}

Reversible cerebral vasoconstriction syndrome with reversible renal artery stenosis Shibani S. Mukerji, Bradley R. Buchbinder and Aneesh B. Singhal

Neurology 2015;85;201-202

DOI 10.1212/WNL.0000000000001740

This information is current as of July 13, 2015

\section{Updated Information \&} Services

References

Subspecialty Collections

Permissions \& Licensing

Reprints including high resolution figures, can be found at: http://n.neurology.org/content/85/2/201.full

This article cites 2 articles, 1 of which you can access for free at: http://n.neurology.org/content/85/2/201.full\#ref-list-1

This article, along with others on similar topics, appears in the following collection(s):

fMRI

http://n.neurology.org/cgi/collection/fmri

Secondary headache disorders

http://n.neurology.org/cgi/collection/secondary_headache_disorders Stroke in young adults

http://n.neurology.org/cgi/collection/stroke_in_young_adults

Information about reproducing this article in parts (figures,tables) or in its entirety can be found online at:

http://www.neurology.org/about/about_the_journal\#permissions

Information about ordering reprints can be found online:

http://n.neurology.org/subscribers/advertise

Neurology ${ }^{\circledR}$ is the official journal of the American Academy of Neurology. Published continuously since 1951, it is now a weekly with 48 issues per year. Copyright () 2015 American Academy of Neurology. All rights reserved. Print ISSN: 0028-3878. Online ISSN: 1526-632X.

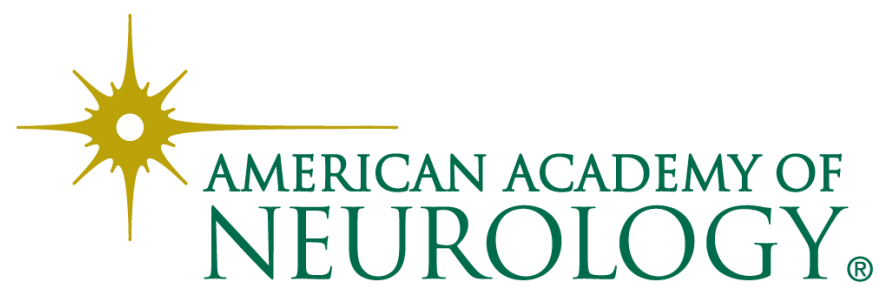

